\title{
Influence of Students' Feedback on the Quality of Science Teaching among Undergraduates in South-West Nigerian Universities
}

\author{
Agboola, Omowunmi Sola ${ }^{1, *} \&$ Olajide, Simeon Olayinka ${ }^{1}$ \\ ${ }^{1}$ Institute of Education, Faculty of Education, Obafemi Awolowo University, Ile-Ife 220005, Nigeria \\ *Corresponding author: Institute of Education, Faculty of Education, Obafemi Awolowo University, Ile-Ife 220005, \\ Nigeria. Tel: 234-806-500-8779. E-mail: omowunmisola@yahoo.co.uk
}

Received: November 13, 2014

Accepted: January 21, $2015 \quad$ Online Published: February 12, 2015

doi:10.5430/wje.v5n1p114

URL: http://dx.doi.org/10.5430/wje.v5n1p114

\begin{abstract}
The study examined the influence of students' feedback on the quality of the teaching of science teaching in four Nigerian Universities: Obafemi Awolowo University Ile-Ife, University of Ibadan, Ibadan, Osun State University, Osogbo and Lead City University, Ibadan. This was aimed at improving students' academic performance in the science disciplines.

The study adopted a survey research design. The population for the study consisted of 346 students in the Faculty of Science and Science Education and in cognate courses in the universities. The students were selected using purposive sampling technique. A 30-item questionnaire each with likert type response format titled "Questionnaire on Influence of Students Feedback on Quality of Science Teaching" (OISFQST) were administered. Data obtained were analyzed using simple percentages, t-test and one way Analysis of Variance (ANOVA).

The results showed that there was no significant difference between gender on perception of students feedback on the quality of science teaching $(t=0.4959>0.05)$. The results also showed that there was no significant difference between institution and the importance of students' feedback on the quality of science teaching $(F=9.01>2.63)$. The results further showed that there was no significant difference between institution on the effect of feedback on the quality of science teaching (F 32.97>2.63).

The study concluded that feedback by students is critical to good teaching and could bring about improvements to the faculty members and to the university at large.
\end{abstract}

Keywords: influence; feedback; science quality teaching

\section{Introduction}

Science is an intellectual activity carried on by humans that is designed to discover information about the natural world in which human live and to discover the ways in which this information can be organized into meaningful patterns and the ultimate purpose of science is to discern the order that exist between and among the various facts (Gottlerb, 2005). It is also the systematic evolution of natural events and condition in order to discover facts about them and to formulate laws and principles based on these facts, also an organized body of knowledge that is derived from such observations that can be verified or tested by further investigation (Academic Press Dictionary).

Science have long been recognized as instruments for nation building in a developing country like Nigeria where means of achieving technological development and economic survival are being sought, high importance is placed on the teaching and learning of science in schools. This is reflected in Section 8 of the National Policy of Education (NPE) where it was stated that, "not less than $60 \%$ of places shall be allocated to science and science-oriented courses in the conventional universities and not less than $80 \%$ in "Universities of Technology" .

Generally it has been revealed that over one billion students and lecturers are not aware of feedback and quality of science teaching in higher institutions of learning in Africa (Pretorious, 2012). Feedback is an essential part of effective learning. It helps students understand the subject being guided and gives them clear guidance on how to improve their learning. Bellon, Bellon \& Blank (1991) stated that academic feedback is more strongly and consistently related to achievement than any other teaching behaviour, this relationship is consistent regardless of grade, socioeconomic 
status, race, or school setting.' Feedback can improve a student's confidence, self-awareness and enthusiasm for learning. Effective feedback during the first year in university can aid the transition to higher education and may support student retention. Providing students engage with feedback, it should enhance learning and improve assessment performance.

The quality of education depends on the performance of their duties by lecturers. The performance of students in examination, whether internal and external, had been used to judge how good the lecturers are in teaching (Ajao, 2001). During interaction with student, the lecturers ultimately translate policy into action and principles based on practice (Afe, 2001). Thus, a lecturer is the one who produces result when trying to do his duty (Uchefuna, 2001). With the huge investment of government in public education, the output is nothing to write home about. The failure rates and the poor quality of students might have been a reflection of the instructional quality in schools and thus the widely acclaimed fallen standard of education in Nigeria.

Students' views on all aspects of their higher education experiences are essential to the effective monitoring of quality in universities (Hill, Lomas and MacGregor, 2003). In the United States of America and in European countries, student evaluation of lecturer's performance is very important for appraising the academic staff (Curtis, 2002; Emery, Kramer and Tian, 2003). This is not the case in Nigeria where qualifications, teaching, current research, publications and service to university/country are used (Mordi, 2002; Adomi and Mordi, 2003). University teachers are also expected to possess content competence, pedagogical competence, the ability to deal with sensitive topics in an open, honest, and respectful way, the ability to contribute to the intellectual development of the student, the ability to treat students' grades, other academic records, and private communications with strict confidentiality, assessment of students that is valid, open, fair and congruent with the course, and respect for the institution (Murray et al., 1996).

Duyilemi (1996) argued that some science academic staff showed positive attitude towards teaching the science subjects while some exhibited negative attitude towards teaching science courses to the students. Aigbomian (1990) have argued that the extent a student prefers a subject, to that extent the student works hard to achieve in it. A close examination of the submissions of Aigbomian (1990) and Duyilemi (1996) revealed that academic achievement may be dependent upon positive attitude from the academic staff and the students in the teaching/learning processes. Quality science teaching occurs when teachers believe all students needs to develop scientific capabilities and conceptual understanding in order to be equipped to live in our society. Also they should believe that students are able to achieve the science outcomes when they engage in effective teaching and learning programs, students should be encouraged to believe they can be successful learner in the area of science. Science teaching should therefore take place in a supportive environment that caters for individual differences, includes opportunity for cooperative and collaborative group work, allow student to engage in sustained conversation and task about the "big ideas" that underpin the achievement of science and technology outcomes, should also include opportunity for substantive interaction between students to students and lecturer to student, encourage sustained effort by students to successfully complete task, provides access to a range of materials equipment and other resources related to science learning.

Many reasons can be attributed to students' poor performance in science. Feedback as a factor that can predict or affect the academic performance of students in sciences has not been thoroughly looked into. It is against the background that the influence of students' feedback is considered necessary.

\section{Statement of the Problem}

The quality of science teaching has been a major problem in the Nigerian contemporary society which can be due to the negligence of feedback; little or no attention has been paid to feedback and its influence on the quality of science teaching. Therefore to ensure quality and adequate science teaching feedback as an integral part of qualitative science teaching must be given adequate attention.

Competent lecturers are most crucial piece in improving student's academic performance in science disciplines. There are so many reasons or factors which can be attributed to student's low performance in sciences. Lack of feedback as a factor that can predict or affect the academic performance in sciences has not been thoroughly looked into although this has been shown to have affected on all disciplines, hence this study.

\section{Purpose of the Study}

The purpose of this study is to investigate the influence of feedback on the quality of science teaching among 
undergraduates in the Faculty of Science in Obafemi Awolowo University, Ile-Ife, University of Ibadan, Ibadan, Osun State University, Osogbo and Lead City University, Ibadan.

Therefore the specific objectives of this study are to:

i. Determine the effect of feedback on the quality of science teaching.

ii. Evaluate the perception of students on feedback on the quality of science teaching

iii. Examine the importance of feedback on the quality of science teaching.

\section{Scope of the Study}

This study focused on the influence of students' feedback on the quality of science teaching among undergraduates in the Faculty of Science in Obafemi Awolowo University, Ile-Ife, University of Ibadan, Ibadan, Osun State University, Osogbo, Osogbo and Lead City University, Ibadan.

\section{Research Questions}

The following research questions were generated for the study:

1. What is the effect of feedback on the quality of science teaching?

2. How can we determine the role of teachers in enabling feedback in learning process?

3. What are the factors that will enable adequate feedback?

\section{Research Methodology}

This discussed the study design, the population, the sample and sample procedures, research instrument, validity and reliability of the instrument. The study adopted descriptive research design which requires the opinion to respond to some variables. The population of this study comprised of all undergraduate students in the Faculty of Science in Obafemi Awolowo University, Ile-Ife, Osun State University, Osogbo, University of Ibadan, Ibadan and Lead City University, Ibadan. The sample consisted of 346 undergraduate students purposively selected from the Obafemi Awolowo University (100), Osun State University (100), University of Ibadan (128) and Lead City University (18). The sampling method or technique adopted for this study was purposive sampling. The research instrument adopted for this work was a questionnaire developed by the researcher and it was titled "Questionnaire on the Influence of Students' Feedback on the Quality of Science Teaching" (QISFQST) and was used to collect data from the subjects. The instrument was rated on a 5-point Likert-type scale . The questionnaire was divided into two sections A and B. Section A focused on the respondent's bio data such as sex, age, level etc. This will enable the researcher in preliminary analysis. Section B consisted of some set of questions which were specifically tailored at examining the influence of feedback on the quality of science teaching in tertiary institutions. For the purpose of this research work, the questionnaire was rated on a 5point likert scale with such category as strongly agree, agree, strongly disagree and disagree, neutral in order to efficiently elicit the exact responses from the respondents.

\section{Validity/Reliability of the Research Instrument}

The research instrument was validated by the researchers' supervisors. Content and construct validity was obtained by the help of the supervisors and other experts. All corrections and constructive criticism raised by the supervisor were taken into consideration in the preparation of the final version of the instrument. Reliability within the survey was obtained by calculating the correlation coefficients for each scale. The Cronbach's alpha coefficient is used and ranges from 0.74 to 0.89 . The mean correlations for this instrument ranged from 0.24 to 0.35 , suggesting there is construct validity underlying each scale.

The research instrument which was the questionnaire was personally administered by the researchers to the respondents in their various institutions of learning. It must be noted that in administering the questionnaire, respondents were informed that confidentiality will be maintained. The respondents were then required to complete the questionnaire as sincerely as they could. 346 copies of the questionnaire were administered and they were all filled and collected back for further analysis. A sample of the questionnaire is attached to the appendix page.

The data collected from the respondents were analyzed using simple percentages, t-test and one way Analysis of 
Variance (ANOVA). This was to facilitate the objective of the various opinions with regards to the questions raised in the study. This focuses on the discussion, analysis and presentation of data on the various results obtained from the survey. The discussion and interpretation herein covers: the socio demographic characteristics of respondent surveyed, discussion on the objectives.

The hypotheses tested were;

1. There is no significant difference between genders on perception of students for feedback on the quality of science teaching, there is no significant difference between institution and the importance of feedback on the quality of science teaching; and there is no significant difference between the institutions on the effect of feedback on the quality of science teaching.

Table 1. Determining the Effect of Feedback on the Quality of Science Teaching

\begin{tabular}{|c|c|c|c|c|c|c|}
\hline & & $\begin{array}{c}\text { Strongly } \\
\text { agree }\end{array}$ & Agree & Neutral & Undecided & Disagree \\
\hline 1 & $\begin{array}{l}\text { I have heard the word student } \\
\text { feedback before }\end{array}$ & $\begin{array}{c}92 \\
(26.8 \%)\end{array}$ & $\begin{array}{c}186 \\
(54.2 \%)\end{array}$ & $\begin{array}{c}33 \\
(9.6 \%)\end{array}$ & $\begin{array}{c}5 \\
(1.5 \%)\end{array}$ & $27(7.8 \%)$ \\
\hline 2 & $\begin{array}{l}\text { Teaching resources are appropriate } \\
\text { for my needs }\end{array}$ & $\begin{array}{c}91 \\
(23.1 \%)\end{array}$ & $\begin{array}{c}157 \\
(39.9 \%)\end{array}$ & $\begin{array}{c}43 \\
(17.9 \%)\end{array}$ & $\begin{array}{c}16 \\
(6.6 \%)\end{array}$ & $\begin{array}{c}39 \\
(12.4 \%)\end{array}$ \\
\hline 3 & $\begin{array}{l}\text { My course develops sense of } \\
\text { ethnical responsibility }\end{array}$ & $91(26.3 \%)$ & $\begin{array}{c}157 \\
(45.5 \%)\end{array}$ & $43(12.4 \%)$ & $\begin{array}{c}16 \\
(4.6 \%)\end{array}$ & $\begin{array}{c}39 \\
(11.2 \%)\end{array}$ \\
\hline 4 & $\begin{array}{l}\text { The feedback I received on my } \\
\text { submitted work is provided in time } \\
\text { to help me improve in my discipline }\end{array}$ & $\begin{array}{c}86 \\
(24.8 \%)\end{array}$ & $\begin{array}{c}139 \\
(40.1 \%)\end{array}$ & $\begin{array}{c}65 \\
(18.8 \%)\end{array}$ & $\begin{array}{c}14 \\
(4.4 \%)\end{array}$ & $\begin{array}{c}42 \\
(12.1 \%)\end{array}$ \\
\hline 5 & $\begin{array}{l}\text { I am more open to different ways of } \\
\text { seeing things as a result of my } \\
\text { experience at the university }\end{array}$ & $\begin{array}{c}120 \\
(34.6 \%)\end{array}$ & $\begin{array}{c}164 \\
(47.4 \%)\end{array}$ & $\begin{array}{c}34 \\
(9.8 \%)\end{array}$ & $\begin{array}{c}15 \\
(4.3 \%)\end{array}$ & $\begin{array}{c}13 \\
(3.7 \%)\end{array}$ \\
\hline 6 & $\begin{array}{l}\text { Some lectures cannot explains } \\
\text { things clearly }\end{array}$ & $\begin{array}{c}134 \\
(38.7 \%)\end{array}$ & $\begin{array}{c}111 \\
(32 \%)\end{array}$ & $\begin{array}{c}65 \\
(18.8 \%)\end{array}$ & $\begin{array}{c}13 \\
(3.7 \%)\end{array}$ & $\begin{array}{c}23 \\
(6.6 \%)\end{array}$ \\
\hline 7 & $\begin{array}{l}\text { Feedback by students is critical to } \\
\text { good teaching }\end{array}$ & $\begin{array}{c}115 \\
(33.0 \%)\end{array}$ & $\begin{array}{c}115 \\
(44.7 \%)\end{array}$ & $\begin{array}{c}43 \\
(12.4 \%)\end{array}$ & $\begin{array}{c}18 \\
(5.2 \%)\end{array}$ & $\begin{array}{c}15 \\
(4.3 \%)\end{array}$ \\
\hline 8 & $\begin{array}{l}\text { Feedback by students brings } \\
\text { improvement not only to the faculty } \\
\text { level but also at the university level }\end{array}$ & $\begin{array}{l}127 \\
(36.7 \%)\end{array}$ & $\begin{array}{c}157 \\
(45.0 \%)\end{array}$ & $43(12.5 \%)$ & $\begin{array}{c}9 \\
(2.6 \%)\end{array}$ & $\begin{array}{c}10 \\
(2.8 \%)\end{array}$ \\
\hline 9 & $\begin{array}{l}\text { Students feedback on teaching will } \\
\text { aid in the development and } \\
\text { improvement of teaching }\end{array}$ & $\begin{array}{c}122 \\
(35.2 \%)\end{array}$ & $\begin{array}{c}149 \\
(43.0 \%)\end{array}$ & $47(13.6 \%)$ & $\begin{array}{c}11 \\
(3.2 \%)\end{array}$ & $\begin{array}{c}17 \\
(4.9 \%)\end{array}$ \\
\hline
\end{tabular}

Table 1 determines the effect of feedback on the quality of science teaching. The result indicated that $82.0 \%$ agreed that they were more open to different ways of seeing things as a result of their experiences at the university, while $3.7 \%$ reported no university influence on their exposure on the ways they see things. Also $81.7 \% \%$ agreed that feedback by students brought improvement not only to the faculty level but also at the university level, while $4.0 \%$ still disagreed to this notion that feedback by students brings improvement. It is also believed by $84.0 \%$ that feedback by students is critical to good teaching, while $2.8 \%$ disagreed to the notion. $78.2 \%$ agreed that students' feedback on teaching will aid in the development and improvement of teaching, while $4.9 \%$ disagreed that the feedback from student teaching will aid in the development and improvement of teaching science. $81.0 \%$ agreed they have heard the word student feedback before, while $7.8 \%$ reported that they have never heard it before. $71.8 \%$ agreed that their course develops sense of ethnical responsibility, while $11.0 \%$ disagreed that their course develops sense of ethnical responsibility. $70.7 \%$ argued in favour of some lecturers been able to explain things clearly and have effect on students' feedback, while $6.6 \%$ disagreed that some lecturers cannot explain things clearly. $64.9 \%$ agreed that the feedback they received on their submitted work is provided in time to help them improve in their discipline, while $12.1 \%$ disagreed on any effect of feedback on works previously submitted. $63.9 \%$ agreed that teaching resources are appropriate for their needs, while $12.4 \%$ disagreed that teaching resources were appropriate for their needs.

Responses showed a higher favour in percentage of the effect of feedback on the quality of science teaching with only few percentage of disagreement overall. 
Table 2. Evaluating the Perception of Students on Feedback for the Quality of Science Teaching

\begin{tabular}{|c|c|c|c|c|c|c|}
\hline & & $\begin{array}{l}\text { Strongly } \\
\text { agree }\end{array}$ & Agree & Neutral & Undecided & Disagree \\
\hline 1 & $\begin{array}{l}\text { My lecturers are extremely } \\
\text { good at explaining things }\end{array}$ & $\begin{array}{c}77 \\
(22.2 \%)\end{array}$ & $\begin{array}{c}160 \\
(46.2 \%)\end{array}$ & $65(18.7 \%)$ & $\begin{array}{c}12 \\
(3.4 \%)\end{array}$ & $32(9.2 \%)$ \\
\hline 2 & $\begin{array}{l}\text { There is improved content } \\
\text { and structure of learning } \\
\text { during teaching }\end{array}$ & $89(25.7 \%)$ & $\begin{array}{c}141 \\
(40.5 \%)\end{array}$ & $68(19.6 \%)$ & $\begin{array}{c}17 \\
(4.9 \%)\end{array}$ & $31(8.9 \%)$ \\
\hline 3 & $\begin{array}{l}\text { I do find my courses } \\
\text { interesting even when the } \\
\text { lecturer is explaining in class }\end{array}$ & $91(26.0 \%)$ & $\begin{array}{c}146 \\
(42.2 \%)\end{array}$ & $\begin{array}{c}54 \\
(15.6 \%)\end{array}$ & $\begin{array}{c}13 \\
(3.7 \%)\end{array}$ & $\begin{array}{c}42 \\
(12.1 \%)\end{array}$ \\
\hline 4 & $\begin{array}{l}\text { My lecturers explain topics } \\
\text { more clearly }\end{array}$ & $75(21.6 \%)$ & $\begin{array}{c}134 \\
(38.7 \%)\end{array}$ & $93(26.8 \%)$ & $\begin{array}{c}17 \\
(4.9 \%)\end{array}$ & $27(7.8 \%)$ \\
\hline 5 & $\begin{array}{l}\text { My lecturers give feedback } \\
\text { on students' progress at the } \\
\text { end of each course }\end{array}$ & $\begin{array}{c}67 \\
(19.4 \%)\end{array}$ & $\begin{array}{c}132 \\
(38.1 \%)\end{array}$ & $77(22.2 \%)$ & $\begin{array}{c}16 \\
(4.6 \%)\end{array}$ & $\begin{array}{c}54 \\
(15.6 \%)\end{array}$ \\
\hline 6 & $\begin{array}{l}\text { My lecturers encourage } \\
\text { student's participation in } \\
\text { classroom discussion }\end{array}$ & $\begin{array}{c}101 \\
(29.1 \%)\end{array}$ & $\begin{array}{c}155 \\
(44.7 \%)\end{array}$ & $53(15.3 \%)$ & $\begin{array}{c}8 \\
(2.3 \%)\end{array}$ & $29(8.4 \%)$ \\
\hline 7 & $\begin{array}{l}\text { My lecturers develop a } \\
\text { structure of course to take } \\
\text { into account individual needs }\end{array}$ & $76(21.9 \%)$ & $\begin{array}{c}128 \\
(36.9 \%)\end{array}$ & $\begin{array}{c}65 \\
(18.7 \%)\end{array}$ & $\begin{array}{c}23 \\
(6.6 \%)\end{array}$ & $\begin{array}{c}54 \\
(15.6 \%)\end{array}$ \\
\hline 8 & $\begin{array}{l}\text { My lecturers uses better } \\
\text { teaching techniques }\end{array}$ & $\begin{array}{c}78 \\
(22.5 \%)\end{array}$ & $\begin{array}{c}127 \\
(36.7 \%)\end{array}$ & $88(25.4 \%)$ & $\begin{array}{c}13 \\
(3.7 \%)\end{array}$ & $\begin{array}{c}40 \\
(11.5 \%)\end{array}$ \\
\hline 9 & $\begin{array}{l}\text { My lecturers are more } \\
\text { interactive in their teaching }\end{array}$ & $\begin{array}{c}84 \\
(24.2 \%)\end{array}$ & $\begin{array}{c}151 \\
(46.6 \%)\end{array}$ & $67(19.3 \%)$ & $\begin{array}{c}12 \\
(3.5 \%)\end{array}$ & $\begin{array}{c}32 \\
(9.2 \%)\end{array}$ \\
\hline 10 & $\begin{array}{l}\text { Course lecturers provides } \\
\text { reading materials to students }\end{array}$ & $\begin{array}{c}94 \\
(27.1 \%)\end{array}$ & $\begin{array}{c}143 \\
(41.3 \%)\end{array}$ & $53(15.3 \%)$ & $\begin{array}{c}14 \\
(4.0 \%)\end{array}$ & $\begin{array}{c}42 \\
(12.1 \%)\end{array}$ \\
\hline 11 & $\begin{array}{l}\text { Lecturers make use of } \\
\text { instructional aids during } \\
\text { teaching }\end{array}$ & $90(26.0 \%)$ & $\begin{array}{c}129 \\
(37.2 \%)\end{array}$ & $63(18.2 \%)$ & $\begin{array}{c}14 \\
(4.0 \%)\end{array}$ & $\begin{array}{c}50 \\
(14.4 \%)\end{array}$ \\
\hline
\end{tabular}

Table 2 evaluates the perception of students on feedback for the quality of science teaching. On availability of reading materials $68.4 \%$ said that their lecturer provided reading materials to students, while $12.1 \%$ disagreed on provision of any reading material by the course lecturers. Lecturers encouraging students participation in classroom discussion was agreed on by $73.8 \%$ as a factor, while $8.4 \%$ disagreed on lecturers encouraging student's participation in classroom discussions. $68.2 \%$ agreed that they do find their courses interesting even when the lecturer is explaining in class, while $12.1 \%$ found it boring. $70.8 \%$ agreed on lecturers been more interactive in their teaching, while $9.2 \%$ disagreed on lecturers been more interactive in their teaching as a factor in determining improvement in feedback. Lecturers been extremely good at explaining things were agreed on by $68.4 \%$ of respondent, while $9.2 \%$ disagreed on lecturers been extremely good at explaining things. $63.2 \%$ reported that their lecturers make use of instructional aids during teaching, but $14.4 \%$ said their own lecturers' do not make use of any instructional aids during teaching. $66.2 \%$ agreed that they now have an improved content and structure of learning during teaching, with $18.9 \%$ disagreed on any improvement in content or structure of teaching. $60.3 \%$ said their lecturers explain topics more clearly, while $7.8 \%$ had the opposite experience. $59.2 \%$ believed their lecturers use better teaching techniques, while $11.5 \%$ disagreed on the techniques used by their lecturer to be one that is good. $58.8 \%$ said their lecturers developed a structure of course to take into account individual needs, while $15.6 \%$ said their lecturer do not develop such structure of work that take individual needs into focus. And $57.5 \%$ student reported their lecturers' give feedback on students' progress at the end of each course, while $15.0 \%$ do not receive feedback at the end of each course.

The result shows an increasing level of disagreement between students perception of feedback by teachers as it affects the quality of science teaching. Even though the result indicates large disagreement by students, this cannot be extensively generalized for all the students. 
Table 3. Examining the Importance of Feedback on the Quality of Science Teaching

\begin{tabular}{|c|c|c|c|c|c|c|}
\hline & & $\begin{array}{c}\text { Strongly } \\
\text { agree }\end{array}$ & Agree & Neutral & Undecided & Disagree \\
\hline 1 & $\begin{array}{l}\text { The course I am studying develops } \\
\text { my problem solving skills }\end{array}$ & $79(22.8 \%)$ & $\begin{array}{c}182 \\
(52.6 \%)\end{array}$ & $43(12.4 \%)$ & $\begin{array}{c}22 \\
(6.3 \%)\end{array}$ & $\begin{array}{c}20 \\
(5.7 \%)\end{array}$ \\
\hline 2 & $\begin{array}{l}\text { I feel a sense of belonging to the } \\
\text { university community }\end{array}$ & $129(37.2 \%)$ & $\begin{array}{c}153 \\
(44.2 \%)\end{array}$ & $\begin{array}{c}32 \\
(9.2 \%)\end{array}$ & $\begin{array}{c}6 \\
(1.7 \%)\end{array}$ & $26(7.5 \%)$ \\
\hline 3 & $\begin{array}{l}\text { My course includes global } \\
\text { perspective }\end{array}$ & $135(39.0 \%)$ & $\begin{array}{c}142 \\
(41.0 \%)\end{array}$ & $\begin{array}{c}26 \\
(7.5 \%)\end{array}$ & $\begin{array}{c}18 \\
(5.2 \%)\end{array}$ & $25(7.2 \%)$ \\
\hline 4 & $\begin{array}{l}\text { There is interaction between I and } \\
\text { my lecturers }\end{array}$ & $88(25.4 \%)$ & $\begin{array}{c}141 \\
(40.7 \%)\end{array}$ & $75(21.6 \%)$ & $\begin{array}{c}6 \\
(1.7 \%)\end{array}$ & $\begin{array}{c}36 \\
(10.4 \%)\end{array}$ \\
\hline 5 & $\begin{array}{l}\text { Student support system is well } \\
\text { improved in my institution }\end{array}$ & $80(23.1 \%)$ & $\begin{array}{c}127 \\
(36.7 \%)\end{array}$ & $59(17.0 \%)$ & $\begin{array}{c}17 \\
(4.9 \%)\end{array}$ & $\begin{array}{c}63 \\
(18.2 \%)\end{array}$ \\
\hline 6 & $\begin{array}{l}\text { There is high level of engagement of } \\
\text { student during teaching }\end{array}$ & $77(22.2 \%)$ & $\begin{array}{c}165 \\
(47.6 \%)\end{array}$ & 67 (19.3\%) & $\begin{array}{c}3 \\
(0.8 \%)\end{array}$ & $34(9.8 \%)$ \\
\hline 7 & $\begin{array}{l}\text { The learning environment is } \\
\text { enabling for communication } \\
\text { between lecturers and students }\end{array}$ & $\begin{array}{c}64 \\
(18.5 \%)\end{array}$ & $\begin{array}{c}163 \\
(47.1 \%)\end{array}$ & $62(17.9 \%)$ & $\begin{array}{c}11 \\
(3.1 \%)\end{array}$ & $\begin{array}{c}46 \\
(13.3 \%)\end{array}$ \\
\hline 8 & $\begin{array}{l}\text { Students participate fully during } \\
\text { lectures }\end{array}$ & $69(19.9 \%)$ & $\begin{array}{c}127 \\
(36.7 \%)\end{array}$ & $83(23.9 \%)$ & $\begin{array}{c}17 \\
(4.9 \%)\end{array}$ & $\begin{array}{c}50 \\
(14.4 \%)\end{array}$ \\
\hline 9 & $\begin{array}{l}\text { Application of contents to } \\
\text { workplace and wide range of } \\
\text { information provided in course } \\
\text { content facilitate a greater } \\
\text { understanding of international } \\
\text { practices }\end{array}$ & $78(22.5 \%)$ & $\begin{array}{c}133 \\
(38.4 \%)\end{array}$ & $\begin{array}{c}88 \\
(25.4 \%)\end{array}$ & $\begin{array}{l}20 \\
(5.8 \%)\end{array}$ & $27(7.8 \%)$ \\
\hline 10 & $\begin{array}{l}\text { Science experiments and teaching } \\
\text { staff gives students more task to } \\
\text { reform during and after class }\end{array}$ & $93(26.8 \%)$ & $\begin{array}{c}167 \\
(48.2 \%)\end{array}$ & $54(15.6 \%)$ & $\begin{array}{c}9 \\
(2.6 \%)\end{array}$ & $23(6.6 \%)$ \\
\hline
\end{tabular}

Table 3 examines the importance of feedback on the quality of science teaching. Global perspective was agreed to be important to feedback by $80.0 \%$, while just $7.2 \%$ disagreed on the importance of global perspective on feedback. $81.4 \%$ agreed that they feel a sense of belonging to the university community due to feedback, while $7.5 \%$ disagreed on any sense of belonging with the university. Science experiments and teaching staff gave students more tasks to reform during and after class was agreed on by $75.0 \%, 6.6 \%$ disagreed that it served as an important factor in enabling adequate feedback. For the ability of the course of study been able to develop one's problem solving skills was agreed on as an important factor in determining feedback by $75.4 \%$, while $5.7 \%$ disagreed on the importance of course of study developing problem solving skills which is meant to enhance feedback. $69.8 \%$ were highly engaged during teaching, while $9.8 \%$ said they were not highly engaged during teaching in the class room. Learning environment enabling for communication between lecturers and students was believed to be an important factor to ensure feedback on science teaching by $65.6 \%$, while $13.3 \%$ disagreed on learning environment. $66.1 \%$ said interaction between them and their lecturers enabled adequate feedback, leaving $10.4 \%$ disagreeing on the student-lecturer relationship enhancing feedback. Students' participating fully during lectures was agreed on by $56.6 \%$ to be important for adequate feedback, while $14.4 \%$ disagreed. And $60.9 \%$ reported that student support system was well improved in their institution, and application of contents to workplace and wide range of information provided in course content was agreed to facilitate a greater understanding of international practices. While $25.4 \%$ and $7.8 \%$ disagreed that student support system was well improved in their institution and application of contents to workplace and wide range of information provided in course content to be important for feedback respectively.

All reports indicate a percentage rate above average for the important of feedback to improve quality of science teaching.

$\mathrm{H}_{0}$ : There is no significant difference between genders on perception of teachers' roles in enabling feedback Test table 
Table 4. t-test on Gender Perception on Feedback

\begin{tabular}{lllllll}
\hline Sex & N & Mean & $\begin{array}{l}\text { Std. } \\
\text { Deviation }\end{array}$ & T & df & Sig.(2-tailed) \\
\hline Male & 189 & 32.5721 & 12.3729 & \multirow{2}{*}{1.013} & \multirow{2}{*}{344} & 0.4959 \\
Female & 157 & 34.2914 & 18.0431 & & & $(>0.05)$ \\
\hline
\end{tabular}

The $t$ test is used to test for a significant difference between genders on perception of students for feedback on the quality of science teaching. A significant value of 0.4959 which is greater than 0.05 the critical alpha value. We therefore conclude by accepting the null hypothesis that there is no significance difference between genders on perception of students on feedback for the quality of science teaching.

$\mathrm{H}_{0}$ : There is no significant difference between institution and the importance of feedback on the quality of science teaching.

Table 5. One Way of Variance (ANOVA) on Institutions and Importance of Feedback

\begin{tabular}{lrrrrr}
\hline Source of variance & SS & df & MS & F & F-table \\
\hline Between groups & 1171 & 3 & 390.3 & & \\
Within groups & 14817 & 342 & 43.32 & 9.01 & 2.63 \\
Total & 15988 & 345 & & & \\
\hline
\end{tabular}

One way variance (ANOVA) was used to test for a significant difference between institution and the importance of feedback on the quality of science teaching. The result showed that there was no significant difference between institution and the importance of feedback on the quality of science teaching ( $F$ value 9.01>2.63). We therefore conclude by accepting the null hypothesis that there is no significance difference between institution and the importance of feedback on the quality of science teaching.

$\mathrm{H}_{0}$ : There is no significant difference between the institutions on the effect of feedback on the quality of science teaching

Table 6. One Way of Variance (ANOVA) on Institutions and the Effect of Feedback

\begin{tabular}{llllll}
\hline Sources of variance & SS & df & MS & F & F-table \\
\hline Between groups & 2812 & 3 & 937.2 & 32.97 & 2.63 \\
Within groups & 9720 & 342 & 28.42 & & \\
Total & 12532 & 345 & & & \\
\hline
\end{tabular}

One way variance was used to test for a significant difference between institutions on the effect of feedback on quality of science teaching. The result showed that there is no significant difference between institution on the effect of feedback on the quality of science teaching ( $\mathrm{F}$ value $32.97>2.63$ ). We therefore conclude by accepting the null hypothesis that there is no significance difference between institutions on the effect of feedback on quality of science teaching.

\section{Discussion}

The findings of this study revealed that teachers' proficiency can only be guaranteed through a constant review of student's feedback if quality service delivery would be achieved. $68 \%$ and this asserts that the conception of teacher quality transcends issues focusing on acquisition of knowledge, skill and attitude to accommodate focus on teachers' accomplishments. The hypotheses tested by the study further buttressed the point that a strong relationship exists between students' feedback and quality of science teaching on the educational activities teachers engage themselves in and the quality of teachers' services delivery. However, this study identified some major constraints such as lack of retention of teachers, inadequate teaching facilities and most importantly teachers' general condition of service. The role of teachers' in the scheme of quality science teaching was confirmed from the findings, when respondents point out that the teachers' role cannot be overemphasized as they can make or mar any educational programme regardless of the quality of its design. Ignoring this and other factors would leave a yawning gap between the goals of quality teachers', service delivery and the continued search for effective implementers of curricula in our Universities.

\section{Summary}

The study showed that university lecturers are apprehensive of students' evaluation of their instructional practices. 
This is probably because of the potential of academic and professional inadequacies that may be exposed by student evaluations especially for junior and less experienced lecturers. Kilpatrick (1997) and Imogie (2000) had reported that senior lecturers tend to have a more positive disposition towards students' evaluation of teaching than junior academics.

This study also showed that lecturers are opposed to these evaluations being used for promotion criteria or any other punitive measures against them. Braskamp and Ory (1994 had reported that lecturers tend to question the practice of deciding issues of promotion, salary and tenure on the basis of anonymous student evaluations most of which have questionable degrees of validity and reliability. Iyamu (1998) had argued that an assessment by students can hardly measure accurately the complexity and multidimensionality of effective teaching. The assessment of lecturers by their students is really a problematic issue. In the light of such constraints, other mean to evaluate and assess teaching effectiveness should be sought.

\section{Conclusion}

Feedback is an essential part of education and training programmes that helps learners to be involved in all areas of their training, points out areas for improvement and actions to be taken to improve the performance.

It is clear by this study that public and private university in Nigeria, teaching effectiveness is currently not assessed. It is also not a criterion for promotion exercise. This implies that the benefits of such exercise are not realized and that lecturers may not have feedback on their teaching and then perpetuates the same mistakes ever the years. Also, students input to learning are also lost. The addition this would have had on staff development is also lost.

This practice is well entrenched in developed countries and should be embraced by universities in Africa. In Nigeria and in Africa at large, lecturers still have the 'large than thou' attitude in our tertiary institutions and this would not be good for the system. In the final analysis, when accepted, results from students' evaluation of teaching in tertiary institutions need to be treated with extreme caution.

\section{References}

Adomi, E. E., \& Mordi, C. (2003). Publication in foreign journals and promotion of academics in Nigeria. Learned Publishing, 16(4), 259-63. http://dx.doi.org/10.1087/095315103322421991

Afe, J. O. (2001). Reflections on Becoming a Teacher and Challenges of Teacher Education. Inaugural Lecture Series 64. University of Benin, Benin City: Nigeria.

Aigbomian, D. (1990). Level of content competence in Physics attained by respective teachers for teaching secondary school Physics in Nigeria. Journal of Science Teachers Association of Nigeria, 27, 63-72.

Ajao, W. (2001). Cadbury is Determined to move Education Forward. Vanguard, December 27 2001, P. 16.

Bellon, J.J., Bellon, E.C., \& Blank, M.A. (1991) Teaching from a Research Knowledge Base: a Development and Renewal Process. Facsimile edition. Prentice Hall, New Jersey, USA.

Braskamp, L.A., \& Ory, J.C. (1994). Assessing Faculty Work. San Francisco: Jossey Bass

Cross, R. (2002). Measuring Quality in Education. New York: El- Kley

Curtis, P. (2002). Lecturers face student assessment. Retrieved October 19, 2005 from http://education.guardian.co.uk/students/story/0,9860,770164,00.html

Duyilemi, A. N. (1996). A quantitative analysis of teachers' attitude toward (improvisation and its attendant problems in Integrated Science. Journal of Educational Research and Evaluation, 1(2), 299-301.

Emery, C.R., Kramer, T.R., \& Tian, R.G. (2003). Return to academic standards: a critique of student evaluations of teaching effectiveness. Quality Assurance in Education, 11(1), 37-46. http://dx.doi.org/10.1108/09684880310462074

Imogie, A.I. (2000). Do You Know who is Teaching Your Child? Benin City: University of Benin Press.

Iyamu, E.OS., \& Aduwa J. (2005). Assessment of the Inquiry-Teaching Competences of Social Studies Teachers in Junior Secondary Schools in Edo State. University of Benin: Benin.

Kilpatrick A. (1997). Another Look at Teaching Evaluation in American Junior Colleges. California: El Camino College 
Mordi, C. (2002). Giving a human face to appraisal criteria of academic staff in Nigerian universities. Perspectives in Education, 18(3), 179-84.

Murry, H., et al. (1996). Ethics in teaching. Retrieved October 30, 2005 from http://web.mala.bc.ca/board/policies/Ethics\%20in\%20Teaching\%20draft\%203.htm

Pretorius, C. (2012). Science Teaching Skills and Quality Developing Countries. Pp 101-105

Richmond, E. (2003). Looking at good teaching. Educational Evaluation, 35(1), 48-59.

Urevbu, A.O. (1997). Creating the Schools We Deserve: Reflections on Education, Pedagogy and Curriculum. Benin City: University of Benin.

\section{APPENDIX I \\ INSTITUTE OF EDUCATION \\ FACULTY OF EDUCATION \\ OBAFEMI AWOLOWO UNIVERSITY, ILE-IFE, NIGERIA \\ QUESTIONNAIRE: ON INFLUENCE OF STUDENTS'FEEDBACK ON THE QUALITY OF SCIENCE TEACHING (QIFSFQST)}

\section{Dear Sir / Ma,}

This questionnaire is designed to elicit information from you on Influence of Feedback on Quality of Science Teaching. All information provided will be treated with utmost confidentiality.

Please tick ( ) on any column you deem appropriate.

\section{SECTION A: DEMOGRAPHIC DATA}

1. Name

\begin{tabular}{|c|c|c|c|c|c|c|}
\hline & & $\begin{array}{c}\text { Strongly } \\
\text { agree }\end{array}$ & Agree & Neutral & Undecided & Disagree \\
\hline 1 & $\begin{array}{l}\text { I have heard the word student } \\
\text { feedback before }\end{array}$ & & & & & \\
\hline 2 & $\begin{array}{l}\text { Teaching resources are } \\
\text { appropriate for my needs }\end{array}$ & & & & & \\
\hline 3 & $\begin{array}{l}\text { My course develops sense of } \\
\text { ethnical responsibility }\end{array}$ & & & & & \\
\hline 4 & $\begin{array}{l}\text { The feedback I received on my } \\
\text { submitted work is provided in } \\
\text { time to help me improve in my } \\
\text { discipline }\end{array}$ & & & & & \\
\hline 5 & $\begin{array}{l}\text { I am more open to different ways } \\
\text { of seeing things as a result of my } \\
\text { experience at the university }\end{array}$ & & & & & \\
\hline 6 & $\begin{array}{l}\text { Some lectures cannot explains } \\
\text { things clearly }\end{array}$ & & & & & \\
\hline 7 & $\begin{array}{l}\text { Feedback by students is critical to } \\
\text { good teaching }\end{array}$ & & & & & \\
\hline 8 & $\begin{array}{l}\text { Feedback by students brings } \\
\text { improvement not only to the } \\
\text { faculty level but also at the } \\
\text { university level }\end{array}$ & & & & & \\
\hline 9 & $\begin{array}{l}\text { Students feedback on teaching } \\
\text { will aid in the development and } \\
\text { improvement of teaching }\end{array}$ & & & & & \\
\hline 10 & $\begin{array}{l}\text { My lecturers are extremely good } \\
\text { at explaining things }\end{array}$ & & & & & \\
\hline
\end{tabular}




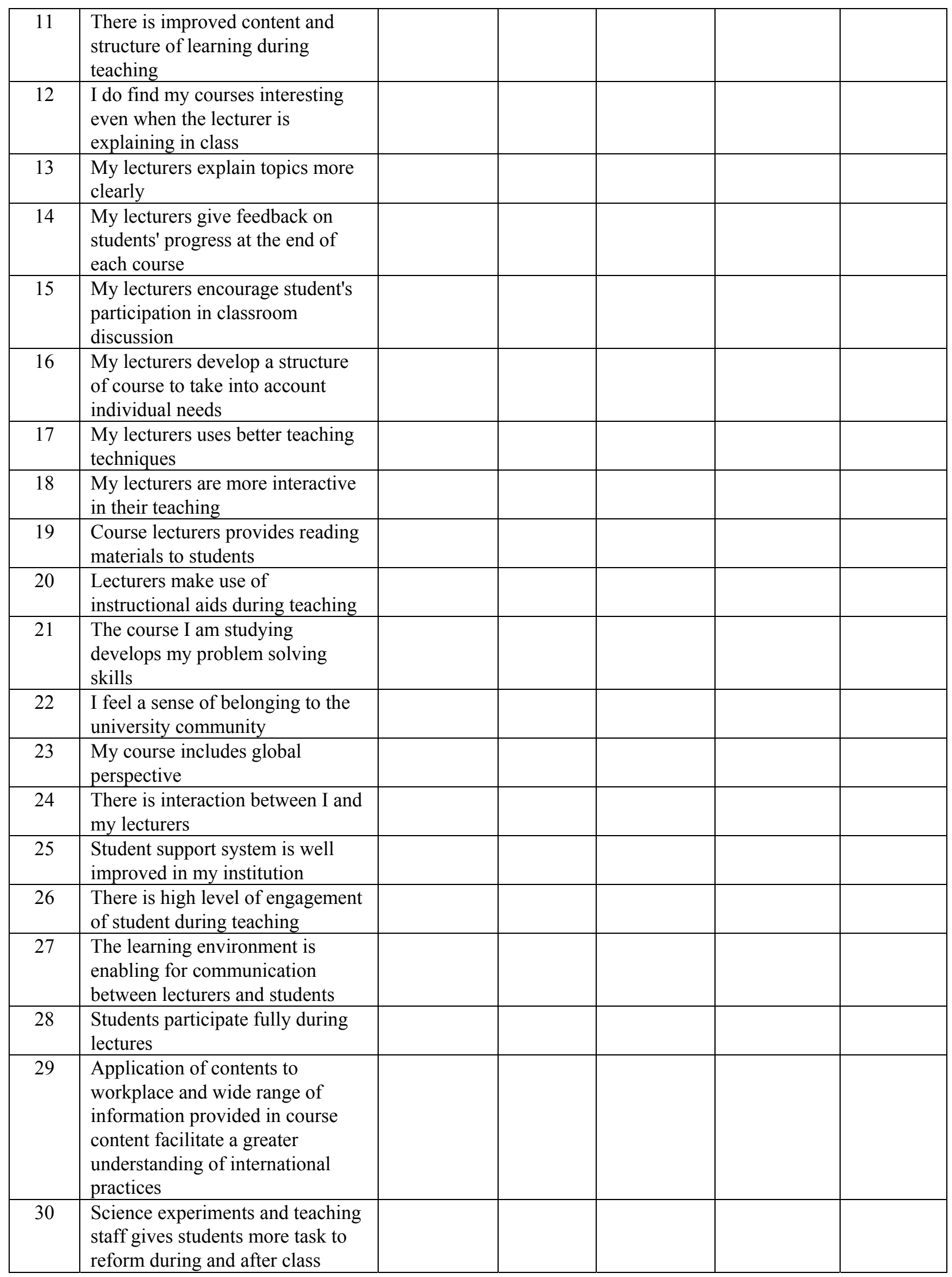

